\title{
PRACTICE OF SUBSISTENCE FARMING SYSTEM IN BHOJPUR, EASTERN HILLS OF NEPAL
}

\author{
Dhyanendra Bahadur Rai
}

\begin{abstract}
Nepalese hill agriculture is a subsistence type of farming system. Development of agriculture follows different trajectories as an outcome of both biophysical and cultural factors for production while culture determines the strategy and the extent of the technological inputs. The main objective of this study is to assess agricultural practice and calculate cost and benefit of crop production in the study area. This study is based on case study of Bhojpur VDC of Eastern hill of Nepal. Data were collected from household survey, key informant interview and field observation. Finding indicates that the crop-livestock combination is the main basis of livelihood of the people in the study area. Land and labor are the main components of the farming system. Maize, potato and millet are traditional crops. Likewise, potato and maize are the most important crops of high zone area. It is cultivated both in irrigated and non-irrigated fields. Paddy is the most important crop in middle zone. Maize, millet and potato are other important crops of this zone. High zone has benefit only in potato production and this zone has no paddy production due to cold climate and no irrigation facility. This zone is deficit in maize and millet production. Middle zone is in benefit only for millet production. Low zone is highly surplus situation in potato, maize and millet but deficit in paddy production. In general, Lower zone is the most suitable area for crop production compared with higher zone areas. However, paddy production is deficit even in lowland area. Cost and benefit analysis indicates that there is low economic return for the farmers in the study area.
\end{abstract}

Key words: Cropping pattern; cropping system; farming system; hill agriculture; subsistence farming system.

\section{INTRODUCTION AND OBJECTIVE}

The subsistence farming system is performed having integration and balance developed by the farmers among agriculture, livestock and forestry maintaining subsistence level of agricultural productivities for

* Mr. Rai is Associate Professor in Central Department of Geography, Kirtipur, TU. 
centuries (Baskota and Sing, 1991). These are indispensable as well as integrated form of combined farming system that are strongly maintained especially in hill farming system where the farmers carry out crop farming as well as livestock farming. When changes take placed in one component in the farming system, it greatly affects the other as a whole in a production system. In such a way the farmers have always understood and maintained the indispensable linkage of the components in integrated manner for long years while the existing relationship of these different practices are taken and understood recently at professional level (Mahat, 1987). The agriculture activities are taken as prominent and relevant which consume the majority of labor force employment in the forms of self employed labor. The farming system and farming technology are very simple and compatible which use of human and animal power. Farmers are completely unfamiliar with the mechanical farming system and they depend on internal (locally available) resources. Agricultural development follows different trajectories as an outcome of both biophysical and cultural factors for production while culture determines the strategy and the extent the technological inputs. Owing to the strong impact of the hill specify people have adopted some specified economic activities. As such for several generations the integrated farming system (crops, livestock and forest) is most common phenomenon. People apply traditional methods of farming, fertilizer, irrigation technique and agricultural equipment.

Many studies have depicted the state of agricultural development from the various part of Nepal. Blaikie, Cameron and Seddon (2005) presented the same scenarios of lack of positive change of the economic and environment. However changes in agricultural system were already noticed after 1950 in the different parts of the country (MoA, 1971) that has reflected as an agricultural diversification (Shrestha \& Katuwal, 1992). The subsistence farming system seems very simple in general but it comprises a complex arrangement. The management of soil, water, crops, livestock, forestry and other resources are within an environment. The management of the farming system is wholly based on performance, capability and technologies of the local farmers. The cropping pattern and cropping system of Nepal hill agriculture have been studied by several researchers but the actual investment and economic output of these types of agriculture system has rarely been studied. Thus the aim of this study is to assess agricultural practice and calculate cost and benefit of crop production which will affect the household income. 


\section{THE STUDY AREA}

\section{Bhojpur District} is located in the hill region of eastern Nepal. Geographically, it extends between $27^{\circ} 1^{\prime} 9^{\prime \prime}$ to $27^{\circ} 12^{\prime} 20^{\prime \prime}$ latitude and $87^{\circ} 1^{\prime} 48^{\prime \prime}$ to $87^{\circ} 4^{\prime} 3^{\prime \prime}$ longitudes. There is Dhankuta district in the east, Khotang in the west, Udayapur in the

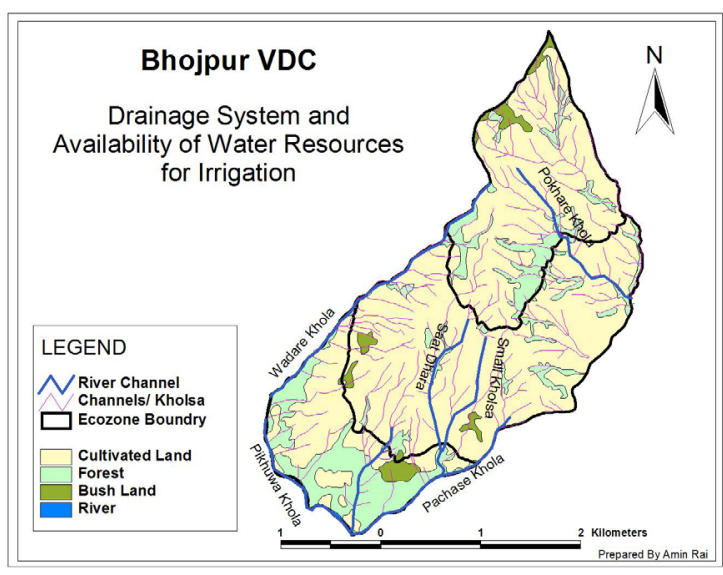
south and Solukhumbu and Sankhuwasava in the north. Bhojpur VDC, the headquarter is situated in the middle part of the district. The VDC has about 5 kilometers areal distance from east to west and about 7 kilometers of north-south. It is hilly region with wide altitudinal variation and diverse climatic conditions within a small area. This VDC extends with quick succession of altitudinal variation from about 700 meter to 2,200 meters above mean sea level. Climatic characteristic is subtropical monsoon in the lower part and warm temperate monsoon in the upper part. Generally rainfall occurs during monsoon particularly from June to September. The onset of rainy season allows for beginning of agricultural activities in this region. There is cold temperate climate around 2,100 meters where winter is cold and sometimes snow fall occurs and summer becomes cool. But there is no paddy farming above the 1600 meters. Grazing land is available in all area. Majority of the people in these areas depends on agriculture, business, services and workers. Settlements in the eastern hill are of dispersed type in general. There are twenty one settlements in Bhojpur VDC within three ecological zones; high zone has six settlements, middle zone has thirteen settlements and low zone has two settlements.

\section{METHODOLOGY}

Study area is divided into three ecological zones on the basis of altitude from mean sea level. These ecological zones are high zone (above 1600 meter), middle zone (1200 meter to 1,600) and low zone (below 1200 meter). According to the District profile of the VDC, the study area has a total of 1,194 households in twenty one settlements. Bazar settlement is 
urban area, where a large number of people are engaged in non-agricultural activities and there are 419 households. So, the study includes only twenty settlements with 775 households except bazar area. This study has selected 15 percent of the household for primary data collection from each settlements selecting randomly from the total households. Random sampling method has been adopted for the study. This study is completely based on quantitative information. Basically, primary data has been collected from field survey. Observation was done carefully during the field survey and was noted in a field note diary. Through this observation method structure of settlements, geo-physical setting, nature of drainage and condition of irrigation, structure of land terrace, grazing and forest were identified matching with topographic map.

From the informal interview with key persons, the information about the conditions of production, livestock situation, fodder and pasture as well as change in crops farming were collected. Villagers like oldest farmer, agriculture expert and government service holders, teachers and other knowledgeable persons were key informants, who could provide information. General information like inter relationship between land, labor and production, changes in crops farming were also taken by this method. This was guided by checklist for key informants' interview. The household survey was done especially for the baseline information. For this purpose, structural questionnaire were prepared. Through this, socio-economic and demographic condition of farm household, composition of livestock and inter relationship between land, labor and production, changes in crops farming were collected. After the completion of field survey, the collected data were categorized and classified into tabular form by applying simple statistical tools like average. The actual cost benefit analysis is the main theme of this paper. It directs the actual situation of hill subsistence farming. For analytical purpose, field data have been converted into money.

\section{ANALYSIS AND RESULT}

Farming System, Cropping Pattern and Cropping system are analyzed systematically under this sub-title. Agriculture is the main basis of livelihood in the rural settlements. The crop-livestock combination is the main basis of livelihood of the people (Koirala, 2006). Land and labor are the main components of the farming system (Chapagain, 2008). This study discusses the relationship between labor inputs and crop production in the following sectors. Agricultural land is the most important resource 
of the study area. Agricultural field is called khet and bari in Bhojpur. The classification of cultivable field such as khet (irrigated terrace), bari (nonirrigated terrace) and pakho (steep slope land) is based upon the dominant crops, availability of water for irrigation, and slope. Agricultural fields are located around the settlement in all the villages. Most of the farmers know about their total land in terms of area, such as hectare or ropani (one hectare equals to 19.657 ropani). With the help of traditional tools and techniques, farmers prepare land for cultivation. Farmers give high priority for preparing land for paddy cultivation. They generally plough khet land before sowing. Farmers plough fields just before sowing seeds where better irrigation facility is not available. Depending on the availability of water for irrigation, farmers usually irrigate khet land before ploughing. After ploughing the field, they spread manure and again irrigate it. In case of less availability of irrigation facility, farmers usually use manure on barren land and then plantation or sowing starts after raining. They apply manure only for maize, wheat and potato. Farmers plough their field with a pair of oxen. Farmers dig the field with spade, one-horn iron tools and a fork like iron tools.

Limited crops are grown in the upper zone area. Maize, potato and millet are dominant crops of this area. Basically, those are cultivated in nonirrigated fields. Paddy is the most important crop in middle zone. Maize, millet and potato are also grown in this zone. All the farmers cultivate paddy if the farmers has their own khet land. Lower zone lies below 1200 meters. Paddy, maize, millet and potato are the major crops of this zone. Bhojpur VDC has three different ecological zones, so crops sowing and harvesting month also different in different ecological zones are follows. Generally, maize is sown in the beginning of April-May and harvested at the end of July/August to beginning of August/September in the lower zone. It is cultivated two times within a season. For the first time the farmers cultivate about 35 days then after three weeks farmers use chemical fertilizer. The farming system depends upon traditional system and weather condition. This traditional pattern of scheduling agricultural activities is still working in the study area. Sowing of paddy starts from the half of March/April and harvest at the beginning of the July/August. The July/August month is the very busy month of the lower zone because it is the time of planting winter rice and harvesting time of maize. After a week the farmers transplant millet in their bari land. Potato is sown in the December/January month and harvest at the end of March/April. In the middle zone, land for paddy and 
maize cultivation in the middle zone is prepared. Farmers use traditional tools and pair of oxen for land preparation. But it depends on precipitation. Then after a week farmers sow maize using manure in their land.

Harvesting starts from the end of July/August to beginning of April/May. July/August month is the time of millet plantation. So, farmers plant millet inside maize land. It is like mixed crops. Transplanting paddy starts from end of June/July to the beginning of August/September month and harvesting month is from end of October/November to beginning of November/December. Paddy weeding month is August/September. December/January is the time of potato sowing with manure and it is harvested in March/April. High zone is the quite different than other zones. There is no paddy farming because of high altitude. Local farmers cultivate potato, maize and millet crops in high zone. Potato is the most important crop of this zone. It is started to plant from last of March to beginning of April month and harvesting month is half August to first September month. Farmers prepare their bari land in February month using manure. Maize is sown in May month and harvested in October. Millet is also an important crop of the high zone. Nursery is prepared in July and the farmer seed transplants millet in August month.

There are different cropping patterns, production and crops types in different altitudinal zones. Cultivation is practiced in all over the settlements and all altitudinal zones. It requires more manure and chemical fertilizer also. Livestock is the main source of manure. Labor is required more for sowing than harvesting. For weeding labor is required little than sowing and harvesting time. Seeds, oxen, human labor, compost and chemical fertilizer are the required materials for potato production. Where 23percentage investment is required only for seed, 30 percentage investment required manure and 4 percentage investment required chemical fertizer respectively. Farmers do not buy compost from other sources it is because they make compost themselves by their own livestocks. Bufflow, cow and ox are the main source of manure. They need 15 percent sowing labor, 4 percentage weeding and 17 percentage harvester. Weeding labor is not needed all ecological zone it just needs in High Zone. According to 
both figures, labor investment cost is minimum (42\%) than other fertilizer investment cost (57\%).

Table 1: Input and Output of Potato Production

\begin{tabular}{|l|r|r|r|r|r|r|}
\hline $\begin{array}{c}\text { Ecological } \\
\text { zone }\end{array}$ & $\begin{array}{c}\text { Area } \\
\text { (Ropani) }\end{array}$ & $\begin{array}{c}\text { Yield/ } \\
\text { ropani } \\
\text { (Muri) }\end{array}$ & $\begin{array}{c}\text { Total } \\
\text { Production } \\
\text { (Muri) }\end{array}$ & $\begin{array}{c}\text { Investment } \\
\text { Cost Nrs./ } \\
\text { ropani }\end{array}$ & $\begin{array}{c}\text { Production } \\
\text { Nrs./ ropani }\end{array}$ & $\begin{array}{c}\text { Cost and } \\
\text { benefit Nrs./ } \\
\text { ropani }\end{array}$ \\
\hline High zone & 47.1 & 12.46 & 587 & 10934 & 12463 & 1529.09 \\
\hline Middle zone & 39.8 & 7.29 & 290 & 7742 & 7286 & -455.78 \\
\hline Low zone & 10.2 & 5.59 & 57 & 4739 & 5588 & 849.02 \\
\hline Total/average & 97.1 & 9.62 & 934 & 8975 & 9619 & 644.08 \\
\hline
\end{tabular}

Source: Field survey, 2013.

The total investment cost and total production cost in every ecological zone. High zone has 47.1 ropani cultivated area for potato production which is the highest cultivated area than other zones. There is the highest productivity. Low zone has just 10.2 ropani of cultivated area. It has lower area and low per area production than other zone. Total production, cultivated area and yield are more in High zone than Middle Zone and Middle Zone has more than Low zone respectively.

Maize is cultivated all over the study area. It requires more chemical and compost fertilizer. Following table shows the maize farming system and labor inputs. At first, Farmers prepare their land by pair of oxen and human labor. Then, they plough maize with manure (compost fertilizer) in their bari land. Two months later they start weeding and after a month farmers repeat weeding using chemical fertilizer. Maize is produced in each zone of the study area and ploughing phase starts since April whereas middle and low zone it starts from May. Maize cropping is most important in this study area because people use it as fodder for livestock making compost. Most of the area of this VDC is suitable for maize production. But a large number of people depend on traditional habituated method. For instance; farmers mainly depend on cattle dung and a little in chemical fertilizer. After five weeks of plantation, chemical fertilizer is used repeatedly. One of the controversial matters is that, it requires more labor cost than the amount of fertilizer. The investment is Rs 2454.49 per ropani area and production is being held worth of Rs 2187.30. But the maize production is in loss position. In hilly region, 597.1 ropani has been cultivated and production 677 muris. Investment cost is Rs 2342.50 but production is Rs 2267.62. same situation exist in the High zone. 
136 PRACTICE OF SUBSISTENCE FARMING SYSTEM IN BHOJPUR, EASTERN ...

Table 2: Inputs and Output of Maize Production

\begin{tabular}{|l|l|l|l|l|l|l|}
\hline $\begin{array}{c}\text { Ecological } \\
\text { zone }\end{array}$ & $\begin{array}{c}\text { Area } \\
\text { (Ropani) }\end{array}$ & Yield & $\begin{array}{c}\text { Total } \\
\text { Production } \\
\text { (Muri) }\end{array}$ & $\begin{array}{c}\text { Investment } \\
\text { Cost Nrs./ } \\
\text { ropani }\end{array}$ & $\begin{array}{c}\text { Production } \\
\text { Nrs./ } \\
\text { ropani }\end{array}$ & $\begin{array}{c}\text { Cost and } \\
\text { benefit } \\
\text { Nrs./ } \\
\text { ropani }\end{array}$ \\
\hline High zone & 324.6 & 1.09 & 355 & 2454.49 & 2187.30 & -267.189 \\
\hline Middle zone & 597.1 & 1.13 & 677 & 2342.50 & 2267.62 & -74.8813 \\
\hline Low zone & 114.3 & 1.20 & 137 & 2028.74 & 2397.20 & 368.4536 \\
\hline Total & 1036 & 1.13 & 1169 & 2342.98 & 2256.75 & -86.2229 \\
\hline
\end{tabular}

Source: Field survey, 2013.

Lower region is profitable than other two zones for maize production. This region has total investment is worth of Rs 2028.74 and the production is worth of Rs 2397.75 . It shows that in low region, total cultivated land is less but the productivity is higher than other two regions because of the availability of modern agricultural system and the common practice of chemical fertilizer.

Millet is also an important crop of the high zone. Seeds are prepared in June and the farmer plants in July and August month. It is cultivated in bari land inter-cropping with maize. Local farmers cultivate millet inside the maize land so it is mixed crop. Table 3 shows the investment cost is Rs 2292.93 per ropani area and production is Rs 1950.53 But the millet production is in loss position in the High region. In middle zone millet is cultivated in 311.5 ropanis and its production is 329.50 muris. Total investment cost is Rs 2364.06 and production is worth of Rs 2538.06 It shows benefit Rs 174.62 in per ropani area. According to the table, it shows that low zone is more profitable than other two regions for millet production.

Table 3: Inputs and Outputs of Millet Production

\begin{tabular}{|l|r|r|r|r|r|r|}
\hline $\begin{array}{c}\text { Ecological } \\
\text { zone }\end{array}$ & $\begin{array}{c}\text { Area in } \\
\text { (Ropani) }\end{array}$ & $\begin{array}{c}\text { production } \\
\text { (Muri/ } \\
\text { ropani) }\end{array}$ & $\begin{array}{c}\text { Production } \\
\text { (Muri) }\end{array}$ & $\begin{array}{c}\text { Investment } \\
\text { Cost Nrs./ } \\
\text { ropani }\end{array}$ & $\begin{array}{c}\text { Production } \\
\text { Nrs./ } \\
\text { ropani }\end{array}$ & $\begin{array}{c}\text { Cost and } \\
\text { benefit } \\
\text { Nrs./ } \\
\text { ropani }\end{array}$ \\
\hline High zone & 141.5 & 0.81 & 115 & 2292.93 & 1950.53 & -342.40 \\
\hline Middle zone & 311.5 & 1.06 & 329.5 & 2364.06 & 2538.68 & 174.62 \\
\hline Low zone & 60.5 & 1.10 & 66.5 & 2304.13 & 2638.02 & 333.88 \\
\hline Total & 513.5 & 1.00 & 511 & 2337.40 & 2388.32 & 50.92 \\
\hline
\end{tabular}

Source: Field survey, 2013. 
In the higher zone, investment is higher than production. However both middle and lower zone has surplus but low zone more profitable than in middle zone.

There is more use of labor in paddy farming in study area. And also the oxen utilization takes 36 percent in paddy production. People use less amount of the fertilizer to grow paddy due to the lack of infrastructure facility in Bhojpuri VDC, (Table 2 and 3 ).

Table 4: Inputs and Outputs of Paddy Production

\begin{tabular}{|l|r|r|r|r|r|r|}
\hline $\begin{array}{c}\text { Ecological } \\
\text { zone }\end{array}$ & Area & $\begin{array}{c}\text { Production } \\
\text { (Muri) }\end{array}$ & $\begin{array}{c}\text { Yeild } \\
\text { (Muri) }\end{array}$ & $\begin{array}{c}\text { Investment } \\
\text { Cost Nrs./ } \\
\text { ropani }\end{array}$ & $\begin{array}{c}\text { Production } \\
\text { Nrs./ } \\
\text { ropani }\end{array}$ & $\begin{array}{c}\text { Cost and } \\
\text { benefit Nrs./ } \\
\text { ropani }\end{array}$ \\
\hline Low zone & 106 & 167 & 1.58 & 3018.73 & 2520.75 & -497.97 \\
\hline Middle zone & 824 & 1165 & 1.41 & 2414.27 & 2262.14 & -152.14 \\
\hline Total & 930 & 1332 & 1.43 & 2483.17 & 2291.61 & -191.55 \\
\hline
\end{tabular}

Source: Field survey, 2012 .

In the low zone of Bhojpur VDC, investment is Rs 3018.73 per ropani for paddy but the outputs is of Rs 2520.75 . It shows that peoples are still at loss. Even Low region, middle zone also faced the same problem for paddy production in study area due to the lack of modernization of agriculture. (Table 4).

\section{CONCLUSION}

Agriculture is the main basis of livelihood for rural farmers in Bhojpur VDC. Majority of the people are farmers and almost all people depend on crop production in the study area. Most of the farmers cultivate on their own farmland. Land management system is almost traditional in this area. The crop varieties are specified to the farmland type e. g, paddy on khet land, maize, millet and potato on bari land. Largest proportion of farmers applies compost manure than chemical fertilizer. The crop pattern and intensity depend on land types. Yield is different in different altitudinal zones. Generally potato yield is higher in the high zone and paddy in the lower zone. The middle zone of the study area is food deficit zone. Livestock sector provides an abundant contribution to the agricultural economy. It is used for manure, meat; milk and ox particularly for land preparation. People follow the indigenous farming system which is practiced since, long from their ancestors. Farming system is subsistence rather than profit making. Most of the people of this area prefer to grow paddy, maize, potato, as well as millet. But people are familiar to grow such kind of crops due to their needs. People do not calculate actual cost and benefit rather than their just 
doing what they are doing from generation to generation for their subsistence. Mostly, the farmers depend on monsoon rainfall for agriculture.

People are unknown about their loss in growing crops since they never calculate cost and benefit. But they manage manure and tools in local level to fulfill their basic needs. High zone has benefit only in potato production and this zone has no paddy production due to cold climate. This zone is deficit in maize and millet. Middle zone benefits only from millet production. Low zone shows surplus situation in potato, maize and millet but deficit in paddy production. In general, lower zone is the most suitable area for crop production compared to higher areas. However, paddy production is deficit even in the lowland areas. Cost and benefit analysis indicates that there is low economic condition of the farmers residing in this area. There is another aspect of farming system because the labour cost is not always paid. They usually work themselves in the fields and sometimes they exchange their labor as Parma (labor exchange) with other farmers. Beside the food grain, farmers produce fruits, spices, broom grass etc as cash crops. So, this type of cost and benefit analysis of only crop production is not sufficient for subsistence agriculture system in the hills of Nepal. It requires to analysis the whole aspect of the system.

\section{WORKS CITED}

Blaikie, P. M., Cameron, J., \& Seddon, J. D. (2005). Nepal in crisis: Growth and stagnation at the periphery (Rev. and Enlarged ed.). New Delhi: Adroit Publishers.

Banskota, M. and Sing, R.V. (1991), Watershed management experience in the Hindukusha-Himalayan region, Theme Papers, MEM Series (2), Kathmandu: ICIMOD.

Chapagain, P.S. (2008). Land, labour and agricultural change in upper Manang Valley: Understanding, meanings and process. Kathmandu: $\mathrm{PhD}$ dissertation, Faculty of Humanities and Social Sciences, TU.

Koirala, H.L. (2006). Livelihood pattern, adaptive strategy and sustainablity of communities in Southern Arun Valley of Nepal Himalayas. India: PhD dissertation, Gauhati University.

Mahat. T. B. S. (1987). Forestry-farming linkages in the Mountains. Occasional Paper (7), Kathmandu: ICIMOD

MoA. (1971). Farm management study in selected regions of Nepal 196869. Kathmandu: Government of Nepal.

Shrestha, H., \& Katuwal, B. (1992). Farmers Strategies in the middle hills of Nepal. In N. S. Jodha, \& T. Partap (Eds.), Sustainable mountain agriculture: Perspectives and issues (Vol. II, pp. 447-476). New Delhi: Oxford and IBH Publishing. 